\title{
Examination of leader communication in agriculture
}

\author{
Krisztina Dajnoki \\ University of Debrecen Faculty of Agricultural Economics and Rural Development
}

\begin{abstract}
My doctoral and research topic was significant in the examination and analysis of leader activities in the framework of a functional, modularly constructed empirical research program of the Department of Management Sciences. I could make statements and correspond about leader activities; these exercises and the influential factors on these activities were studied by the examinations and analyses of leader communication. In this article, I will demonstrate the research I made in on agricultural communication, as a Ph.D. student in the Department of Management Sciences.
\end{abstract}

Keywords: agricultural organisation, leader communication, interactioin examinations

\section{Programmes}

- The aim of my doctoral dissertation is to examine the factors influencing communication in agricultural organisations, on the basis of professional literature and my own observations.

- My aim was to define and explain the idea of leader communication using data from the literature and theoretical approximations.

- The aim of leader observations was to analyse and evaluate leader activities, the composition and the structure and rates of leader activities by the time-study and content analysis of communication. My aim was to form a research method by interaction examinations that can be suitable for making management examinations. Based on these data, I performed cluster analyses and possibility estimations.

- The final aim of my examinations was to analyse the influential factors of leader communications.

\section{Literary overvie}

Communication is not separated from management. Communication is management or more precisely, management is communication. If we want to lead people correctly, we have to communicate correctly (D'Aprix, 1982). It is evident that the realisation of management activities is possible by communication. If this is true, then we must accept as fact that the activities of managers can be examined by how they communicate. The statement that management is communication is too brief. Management is more than just communication, because it contains such elements as personality and style. It is obvious that these factors emerge in communication.
Communication skills are a fundamental part of every managerial activity. Many people think communication is simple because they communicate without conscious thoughts or efforts. However, communication is usually complex, and the opportunities for sending or receiving the wrong messages are innumerable (Daft, 1997). According to Hackley (2005) bad communication is the reason behind many negotiation mistakes, so it is important to learn to communicate in a way that we should reach the result we expected.

According to Mintzberg (1978), the greatest part of managerial activities is said to be verbal communications. Other examinations argue that the mean time of a leader is split between similar communication forms (figure 1). This division shows that listening to others is the most important part; minimally, it is the most substantial part of managerial communication. On average, a leader uses $75 \%$ of his communication time by speaking and listening (Berde, 2003).

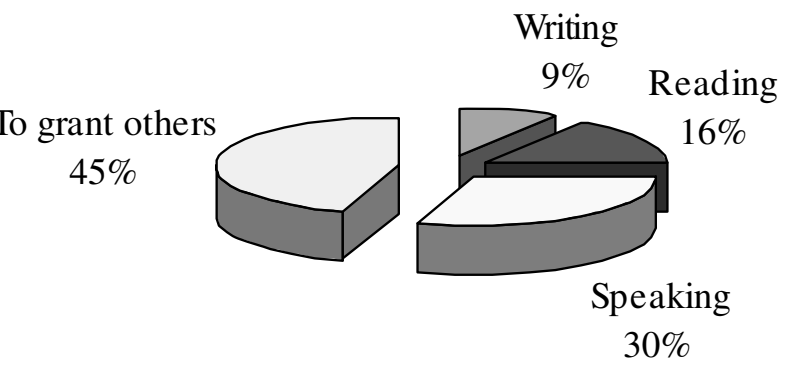

Figure 1: Leader's time division between communication forms Source: Berde (2003)

Roóz (2001) thinks the reason for the crucial importance of management in organisational communication is the high loss of information at different managerial levels (figure 2). 


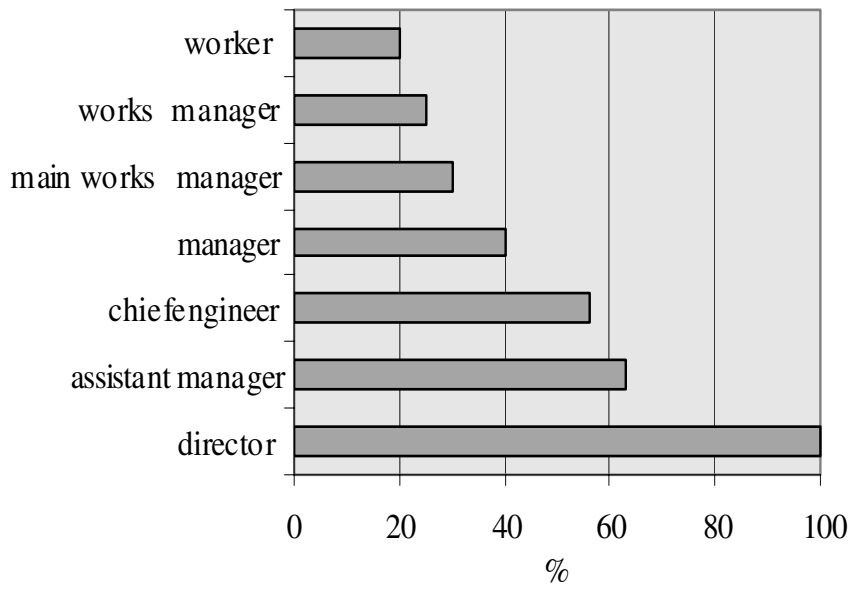

Figure 2: Information loss due to inadequate communication according to Roóz (2001)

Data in the chart show what an important role top managerial level has in the success of communication. Information filtering processes in downward and upward communication are equally relevant. We are neither perfect information senders nor perfect information receivers. Consequently, it is hard enough to receive and perfectly repeat a message when distributing it to other persons. We filter one part of the message and consciously or unconsciously add our prejudices. The same applies to downward communication in organisations, when information goes from the council of directors through assistant managers, CEO, factory directors, factory leaders to workers: communication loses $80 \%$ of its information content. Such a high rate of information loss endangers the activity of an organisation.

Different managerial levels have different information needs. The managerial pyramid can illustrate the flow of information between different levels. Anthony (1965) first introduced this model and it proved to be the most suitable approach, if we examine traditionally constructed organisations from a managerial viewpoint (figure 3).

It seems obvious that by going up on this pyramid, required and provided information changes towards

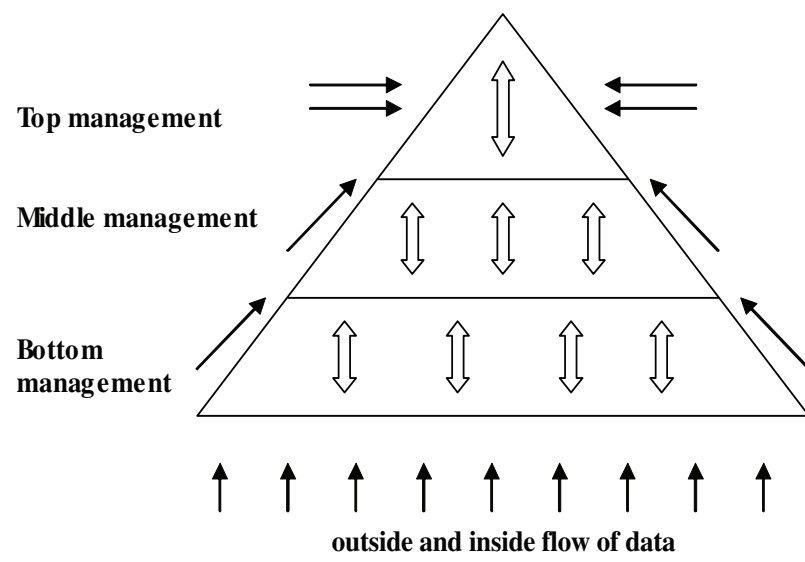

Figure 3: Managerial pyramid according to Anthony (1965) financial, business-political and marketing-political fields. At the same time, subfields should be continuously connected: this means a kind of informational integration.

We distinguish between inner and outer communication circles in corporate communication. Outer communication circles refer to corporate relationships outside the company. Inner communication circles are oriented to form relationships inside organisations and, in this way, they have great influence on coordinating the organisation's function (Gróf, 2001).

At the top managerial level, information cannot go into details. The widest connections should always be summarised into reports and main points should be highlighted by offering solutions for the given situations. The middle managerial level generally deals with more organisational units, groups. These require separated/ individual direction and information on coordination at the same time (Lawler and Rhode, 1976). Information received by middle level managers should be properly detailed and precisely reported. According to Dobay (1997) one cannot perform an intervening managerial activity from a late, wrongly formatted report. So the most important factor at this level is timeliness, planning and compliance with them.

Bottom level managers deal with directing direct subordinates. At this level, information supply should be adequate to solve production level problems on the spot.

Leader communication is a decisive part of organisational communication, in which the communicational specialities of realizing leader activities emerge. Since both internal and external information target managers, at the top manager it reaches its highest concentration. Therefore, the top manager is in the centre of both communicational systems (figure 4). In the performance and direction of internal and external communicational processes, top managers and owners have a determining role.

Information for top managers has to be highly selected in the case of the efficient communication. In internal upward communication the concentration and elaboration of information are increasing as the information reaches higher levels of hierarchy, so information gets to the top manager in the most concentrated, most elaborated and selected form.

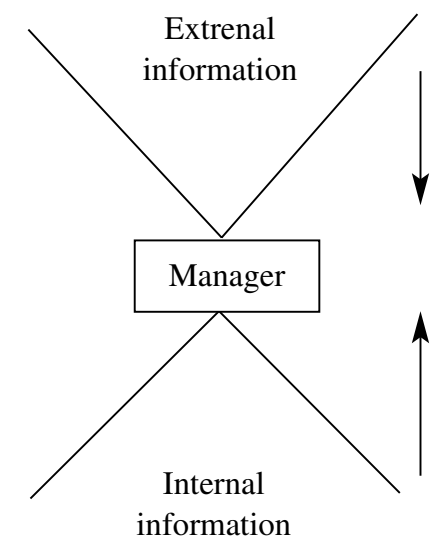

Rate of selectivity

Rate of concentration, rocess

Figure 4: External and internal information concentrates on the manager 
This selection is made by external communication channels on a low level, so it is practical to establish such an organisational part that monitors, collects and selects this information. Bigger organisations can employ internal staff or internal organisation for this function, but micro, small, and medium enterprises must use this as a service using external organizations.

According to Haire (1977), the most important and most trustful exercise is to realise and utilize communication systems. By communication, managers control the work of subordinates, define the aims of organisations and workgroups, and inform the subordinates on their expectations and on the instruments and resources they have. Effective and productive organisational function is unimaginable without adequate internal communication.

\section{Precedents and applied methods}

I did my research as part of the "Functional examination of agricultural corporate management" research programme, worked out by the Department of Management Sciences at University of Debrecen in 1994. My research area formed a part of investigations on organisational management, called organisational communication. I conducted surveys as a part of this theme about professional and leader communications.

I made my observations on leader communications in 6 six corporations in the North Great Plain Region, from 2002 to 2005. The selection of examined corporations was based on two points:

1. The Owner must be the superior leader of the organization. Of the studied organizations, five had just one owner and in one organization, the biggest part was lead by owners.

2. Another important viewpoint was the income. As regards income and result, the examined corporations were medium sized corporations in the county. The income of the corporations almost reached or passed the 2 billion HUF.

The aim of the research is to show and analyse prime and subordinate managers' activities and management practices in the examined organisations by communication examinations on diversified managers.

The basis of my investigations was Mintzberg' study (1979), which observed all the activities performed by five leaders and recorded their time values. His research showed first of all that data could feature leader communication. Based on this examination, he defined and sorted leader functions. Therefore, we can make statements on the parts and exercises of leader activities by the observation and analysis of leader communication.

In leader communication examinations, I measured and analysed the time period of communication parts. The time periods were based on time-work studies.

In the observations, my aim was to examine the prevalence of communication activities by the time value analyses and time period analyses of communication parts.
I made my time period analysis with both superior and subordinate leaders for five workdays. The total observation time was 36359 minutes, which is more than 600 hours.

Grouping the communication elements by time period does not give a good chance to examine leader activities realized by communication. Thus, I realized the analysis of all communication interactions by the data of workday recording. I called this "interaction examination". The aim of these examinations was to identify the most important realized activities by the observed leaders, to make conclusions that could be used to make leader activities more rationalized and more effective. Through my observations, I identified 4797 interactions in the six corporations.

\section{Preparation and analysis based on leader communication examinations:}

- With descriptive statistical methods: time value analysis on superior leaders' communication, time value analysis on subordinate leaders, comparative analysis of time value in superior and subordinate leaders' communication, characterization of interactions by superior and subordinate leaders, comparison of the number of interactions in superior and subordinate leaders' communication.

- I made feasibility evaluations by log-linear methods and I created the next models from my examination: a model set up for communication modes and leader types, a model for communication modes and leader types regarding organizations, a model for interactions and leader types, a model for interactions and leader types regarding organizations.

Due to the nature of my research and the applied examination methods used, I collected different data about different models with different methods. I had to use diverse mathematical and statistical research methods because of the character, the nature, the grouping and evaluating potentials of the collected data. The data collected in leader communication examinations were evaluated with clusteranalysis and log-linear evaluation.

\section{Log-linear analysis}

I made interaction examinations by leader communication observation, time study and leader communication content analysis. I tried to find the answer as to how often different leader activities appear in leaders' work. I based the log-linear analysis on collected interaction data. I analyzed the time values of communication modes and the interaction data of observed organisations and leaders with the General Log linear Analysis method. I used LEM (Log linear and event history analysis with missing data using EM algorithm) software Vermunt (1997). The log-linear method is a multivariable frequency table analysis that can determine the probability of a factor getting into the cells of the table.

The main aim of the log-linear analysis is to find the best model suited for the mass of data, which is not much different 
from a "full saturation" model. Generally, I used few variables in my models, so I used full saturation models where there was not any chance of limitation. This is why this method best suited my aims and revealed the relations I expected.

In addition to the log-linear analysis, I found it appropriate to forecast the cell frequency in case of the six organisations in the sample. My aim was to demonstrate the relative importance of different independent variables (communication mode, interaction) by the forecast of dependent variable values (hours spent on communication modes, number of interactions). The accuracy of models was tested by a reliability test method called ,likelihood ratio test".

The log-linear analysis analyzes tables without the demand to give a dependent variable. The observed frequencies stand in the centre of the method, which is absolutely suitable for my research and establishes the accuracy and usage of the method. By the analysis we can demonstrate frequencies from the table with parameters that we can explain. The aim of the analysis is not to find and explain parameters that are not equal with zero.

The general form of the model:

$\log m_{i j k}=u+\lambda_{i}^{A}+\lambda_{j}^{B+} \lambda_{k}^{C+} \lambda_{i j}^{A B}+\lambda_{i k}^{A C}+\lambda_{i k}^{B C}+\lambda_{i j k}^{A B C}$

where:

$m_{i j k}$ is the frequency of the $i j k$ cell of the table that consists of $\mathrm{i} * \mathrm{j} * \mathrm{k}$ cells

$\lambda$ parameters belong to the effect of appropriate variables

$u$ constant parameter

In case of leader communication examinations:

$A$ communication modes and number of interactions

\section{$B$ type of leader \\ $C$ examined organisations}

The log-linear analysis is not a general method, because it can be established with special software and it is difficult to explain parameters, especially in SPSS. LEM is one of the most important types of software for probability estimations. In the model, we can set the number of variables (lab), how variables exist in the model (man), the number of variable categories (dim) and the model itself. The software calculates the conditional probability by these inputs.
The use of the log-linear analysis can be considered new in this research area; very few people performed this kind of examination in foreign and domestic studies. Domestic studies are mostly methodical innovations and they are accomplished in economic, biological and social research areas. I would say that in the area of management sciences until now, the log-linear method has not been used. I could not find traces of it in the technical literature.

\section{The main conclusions}

In leader communication examinations, I tried to find the answers for the importance and role of the communication in leader activities, the time values and different communication methods in leader activities.

The distribution of data and ranking by the average time value of the examined methods is shown in Table 1 . The five days I spent on observing superior leaders were substantially longer than the observation time for subordinate leaders. The reason for this difference is that while subordinate leaders have fixed working time schedules, superior leaders have flexible working times. This means that superior leaders' working time is determined by the problems they have to solve. A daily $12-14$ hour working time is average, but 23 hours were observed as well. The observed leaders worked
Table 1: Time values in superior leaders' communication

\begin{tabular}{|c|c|c|c|c|c|c|c|c|c|c|}
\hline \multirow{3}{*}{ Communication modes } & \multirow{3}{*}{$\begin{array}{c}\text { Total } \\
\text { minutes }\end{array}$} & \multirow{3}{*}{$\%$} & \multicolumn{8}{|c|}{ Unit: minute } \\
\hline & & & \multicolumn{6}{|c|}{ In organisational dissociation } & \multirow{2}{*}{ Par } & \multirow{2}{*}{ Rank } \\
\hline & & & A1 & B1 & $\mathrm{C} 1$ & D1 & E1 & $\mathrm{F} 1$ & & \\
\hline Telephone (outgoing) & 2175 & 11 & 441 & 515 & 132 & 353 & 298 & 436 & 363 & 4 \\
\hline Telephone (incoming) & 698 & 4 & 110 & 81 & 157 & 112 & 90 & 148 & 116 & 7 \\
\hline $\begin{array}{l}\text { Direct verbal } \\
\text { communications } \\
\text { (official-inside } \\
\text { corporation) } \\
\end{array}$ & 7850 & 41 & 1284 & 713 & 1926 & 1514 & 998 & 1415 & 1308 & 1 \\
\hline $\begin{array}{l}\text { Direct verbal } \\
\text { communication } \\
\text { (official - with client) }\end{array}$ & 2605 & 13 & 364 & 757 & 181 & 376 & 529 & 398 & 434 & 2 \\
\hline $\begin{array}{l}\text { Direct verbal } \\
\text { communication (with } \\
\text { other official } \\
\text { organisations) }\end{array}$ & 1177 & 6 & 199 & 265 & 125 & 219 & 239 & 130 & 196 & 5 \\
\hline $\begin{array}{l}\text { Direct verbal } \\
\text { communication (non- } \\
\text { official) }\end{array}$ & 536 & 3 & 102 & 45 & 120 & 95 & 72 & 102 & 89 & 9 \\
\hline $\begin{array}{l}\text { Written } \\
\text { communication } \\
\text { (writing, electronic, } \\
\text { fax) }\end{array}$ & 362 & 2 & 40 & 97 & 43 & 54 & 72 & 56 & 60 & 10 \\
\hline To grant others & 794 & 4 & 212 & 124 & 59 & 139 & 165 & 95 & 132 & 6 \\
\hline Reading & 656 & 3 & 127 & 127 & 74 & 63 & 146 & 119 & 109 & 8 \\
\hline $\begin{array}{l}\text { Statement without } \\
\text { communication }\end{array}$ & 2444 & 13 & 981 & 141 & 100 & 292 & 569 & 361 & 407 & 3 \\
\hline Totally: & 19297 & 100 & 3860 & 2865 & 2917 & 3217 & 3178 & 3260 & 3216 & \\
\hline
\end{tabular}

Source: Own examinations, 2002-2005 
Table 2: Time values in subordinate leaders' communication

\begin{tabular}{|c|c|c|c|c|c|c|c|c|c|c|}
\hline & & & & & & & & & nit: $m$ & inute \\
\hline \multirow{2}{*}{ Communication modes } & \multirow{2}{*}{$\begin{array}{l}\text { Total } \\
\text { minutes }\end{array}$} & \multirow{2}{*}{$\%$} & \multicolumn{6}{|c|}{ In organisational dissociation } & \multirow{2}{*}{ Par } & \multirow{2}{*}{ Rank } \\
\hline & & & A2 & $\mathrm{B} 2$ & $\mathrm{C} 2$ & D2 & $\mathrm{E} 2$ & $\mathrm{~F} 2$ & & \\
\hline Telephone (outgoing) & 489 & $3 \%$ & 54 & 95 & 96 & 83 & 69 & 92 & 82 & 7 \\
\hline Telephone (incoming) & 254 & $2 \%$ & 17 & 23 & 86 & 42 & 57 & 29 & 42 & 9 \\
\hline $\begin{array}{l}\text { Direct verbal } \\
\text { communications } \\
\text { (official-inside } \\
\text { corporation) }\end{array}$ & 9147 & $54 \%$ & 1693 & 1378 & 1395 & 1425 & 1658 & 1598 & 1525 & 1 \\
\hline $\begin{array}{l}\text { Direct verbal } \\
\text { communication } \\
\text { (official - with client) }\end{array}$ & 740 & $4 \%$ & 0 & 232 & 136 & 112 & 198 & 62 & 123 & 6 \\
\hline $\begin{array}{l}\text { Direct verbal } \\
\text { communication (with } \\
\text { other official } \\
\text { organisations) }\end{array}$ & 384 & $2 \%$ & 80 & 90 & 23 & 54 & 39 & 98 & 64 & 8 \\
\hline $\begin{array}{l}\text { Direct verbal } \\
\text { communication (non- } \\
\text { official) }\end{array}$ & 1042 & $6 \%$ & 0 & 108 & 522 & 85 & 189 & 138 & 174 & 4 \\
\hline $\begin{array}{l}\text { Written } \\
\text { communication } \\
\text { (writing, electronic, } \\
\text { fax) }\end{array}$ & 1695 & $10 \%$ & 297 & 471 & 80 & 368 & 185 & 294 & 283 & 3 \\
\hline To grant others & 244 & $1 \%$ & 45 & 32 & 79 & 42 & 31 & 15 & 41 & 10 \\
\hline Reading & 1018 & $6 \%$ & 141 & 180 & 188 & 195 & 135 & 179 & 170 & 5 \\
\hline $\begin{array}{l}\text { Statement without } \\
\text { communication }\end{array}$ & 2049 & $12 \%$ & 451 & 496 & 48 & 382 & 298 & 374 & 342 & 2 \\
\hline Totally: & 17062 & $100 \%$ & 2778 & 3105 & 2653 & 2788 & 2859 & 2879 & 2844 & \\
\hline
\end{tabular}

Source: Own examinations, 2002-2005

an average of 3216 minutes a week; that means 10 hours and 43 minutes' working time per day. I presume that zeal for hard work is the result of possessing an owner's stake. Unofficial communication with subordinates inside organizations has the highest rate in the ranking of all the 6 leaders. It can be concurred with the theory that the highly important factor for superior leaders is to get information inside their corporation. Unofficial or official verbal communication with clients got the highest qualification in 5 organisations. Owner leaders show primary competency in the range of communications outside the corporation, and it is typical that these activities are delegated on a low level.

On the basis of the results, it can be concluded that the examined leaders spend the least time with written communication and non-official direct verbal communication. Having surveyed the pairs, it can be stated that they spend the third least time on reading. The examination of rates in organizational dissociation reading has the lowest rate in two organizations and incoming telephone calls have the lowest rate in three organizations.

For all subordinate leaders, "direct, official, insidecorporation" communication methods have the longest periods (Table 2). The next is "statement without commu- nication". They spend the least time on "granting others", "incoming telephone calls" and "direct verbal communication with official organisations". They have official conversations with superior leaders. They spend most of their time on "communication with subordinates" and "statement without communication".

As my comparative examination shows, upper level leaders have fewer tasks, but their specific time usage for these tasks is much higher. Upper level leaders have problems that need more time to solve, but they are strategically important and significant from the aspect of the organisation. The activity of subordinate leaders is the reverse, meaning that they solve more problems, but their specific time usage is lower.

My time-study observations of leaders' tasks provided an opportunity to make interaction examinations on communications. A communication process can be defined as an interaction between participants. Having examined the subject of interaction, I could identify the types of leader tasks. Based on the results of these examinations, I demonstrated how often and how importantly leaders' tasks emerge in leaders' activities and the types of correspondences and differences in the activities of different leader levels.

As my findings suggest, there are low rates and numbers of interactions in the communication of upper leaders (figure 5 ). This means that they make relatively few decisions, but these decisions are very important for the organisation and tend to solve problems. The rates of subordinate leaders' interactions show that their competence is strongly limited to realize technological processes.

If we compare the interactions of leaders, we can state that official conversations have the biggest rate, more than $1 / 5$, independently from assignments. We can observe the biggest difference in the comparison of the direction of information flow outside corporations, because it is four times higher for superior leaders than for subordinate ones. The ratio of meetings for superior leaders is five times more but the ratio of information flow inside corporations is more significant in the case of superior leaders as well. Nonofficial conversations have almost equal ratio in leader communication. The proportion of other interactions was 


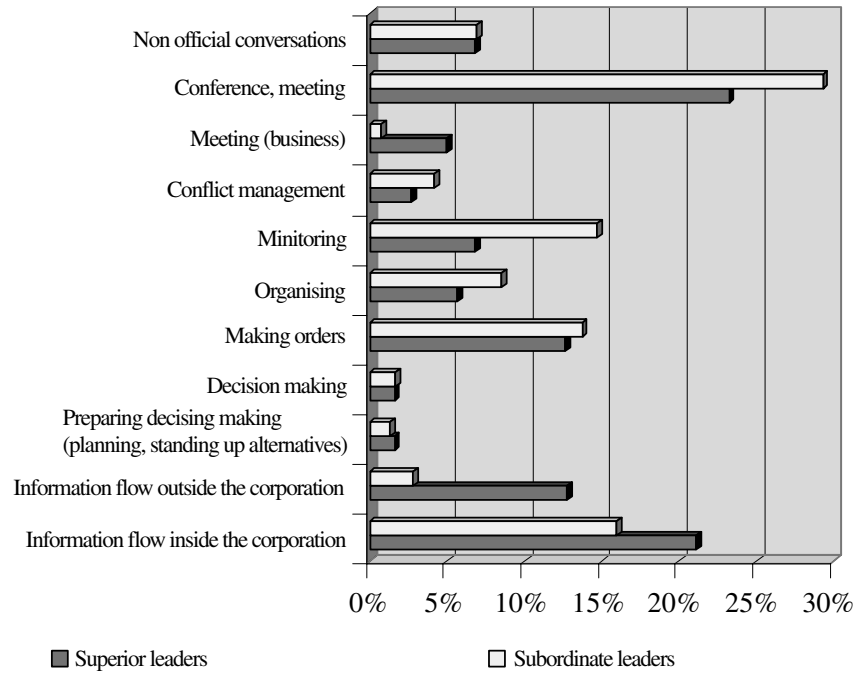

Figure 5: Comparison of superior and subordinate leaders' interactions

higher unambiguously for subordinate leaders. The biggest difference is observed in the ratio of monitoring, because it is two times higher for subordinate leaders than for owners.

I performed log-linear examinations on the basis of the data I collected from my leader communication examinations. My aim was to examine the probability of leader interactions in different assignment leaders in the six studied organisations. I analysed the number of interaction data for every observed organisation and leader by the method of General Log linear Analysis. With the LEM software I constructed a probability theory for interaction data. The program part of the model set up for interactions and leader types:

where:

man $3 \quad$ A the types of interaction (11)

$\operatorname{dim} 1126$ B observed leaders (superior, subordinate) (2)

lab A B C C observed organisations (6)

$\bmod \mathrm{B} / \mathrm{A} \quad \mathrm{B} / \mathrm{A}$ connections between leaders and interactions, conditional probability

From the output of the running programme we can establish the probability percentage of interactions for different leaders. On the basis of the results, I made the following statements:

- Of the identified 11 interaction types, only two have higher probability ratios for superior leaders. The chance of receiving information outside the corporation is triple (74.14\%), meeting has four times higher chances in superior leaders than in subordinate leaders.

- An observation on the chances of monitoring interactions shows they are the highest for subordinate leaders (77.32\%); this means three times higher results than for superior leaders. Next is conflict management (71.02\%) compared to organisations $(70.51 \%)$. For these, the chances are two times higher than for subordinate leaders.

- Occurrence probability for other interactions is under $70 \%$ for subordinate leaders. The probability of meeting and sitting is $66.59 \%$, order and disposal are $63.22 \%$, decision making is $62.96 \%$ and non-official conversation is $61.63 \%$.

- Information flow inside corporations and decision planning $(56.52 \%)$ has the lowest ratio $(54.52 \%)$, so the chance to identify these interactions for subordinate leaders is merely $4-6 \%$ higher.

The other model made for interactions and leader types was completed by organisations. The program part is:

\section{man 3 where:}

$\operatorname{dim} 1126 \mathrm{~B} / \mathrm{AC}$ is conditional probability in connection lab A B C between interactions and leaders considering mod B/A organisations, where AC means common occurring probability.

The running results of the programme show the occurrence probability of identified interactions by organisations and leaders. The log-linear analysis strengthens the results of descriptive statistical methods. On the basis of the analysis of the observed organisations, it can be established that the probability to find superior leaders at meetings or identifying information flow outside corporation occurred during a visit. The probability of organisational, monitoring and conflict management interactions is higher for subordinate leaders.

\section{Summary}

I made my own definition for the examined leader communication on the grounds of the literature and theoretical examinations. Leader communication is a determining part of organisational communication, in which the communicational specialities of realizing leader activities emerge. Leader communication is mainly important from the viewpoint of operating the organisation, because it has a central position in communication, in both incoming and outgoing information for leaders. Information reaches the highest concentration at the level of superior leaders. Superior leaders are in the centre of the two communications.

It can be established on the basis of the communication examination results on upper leaders that they are overaccused. Their average work time in the examination period was 10-12 hours. The reason for this situation is that they do not delegate their tasks or they do not divide their tasks properly. Their communication leader tasks are not differentiated suitably according to their positions, so they take care of each identified leader task on equal level. This means there is a tendency that they take over some tasks from lower levels of management, rather than delegate their own tasks.

It can be established that a communication activity which is absolutely the competency of superior or subordinate leaders does not exist. Based on the result of interaction examinations on superior leaders' interactions, the diagram is not in harmony with their activities. It can be concluded that 
there is harmony between decision making, meeting and conflict management interactions and assignments for superior leaders. There is a contradiction in the ratio of getting information inside and outside corporations. The ratio of organisational, monitoring and order interactions is similarly high.

\section{References}

Anthony, R. N. (1965): Planning and Controll Systems: A Framework for Analysis. Graduate School of Business, Harvard University

Berde CS. (2003): Menedzsment a mezőgazdaságban. Vezetési módszerek és sajátosságok. Szaktudás Kiadó Ház, Budapest, 174-202. p.

D'Aprix, R. (1982): Communicating for Productivity, Harper and Row. Publishers, New York, p. 27.

Daft, R. L. (1997): Management, The Dryden Press, Chicago, 558-565. p.
Dobay P. (1997): Vállalati információmenedzsment. Nemzeti Tankönyvkiadó, Budapest, 23-85. p.

Gróf A. (2001): A vállalat kommunikációs kapcsolatrendszerének szerepe. Marketing és menedzsment, XXXV. 4. Budapest

Hackley, S. (2005): Can You Break the Cycle of Bad Communication? Harward Business Review, May 1.

Haire, M. (1977): Pszichológia vezetőknek. Mezőgazdasági Kiadó, Budapest, 61-75. p.

Lawler, III. E. E., Rhode, J. G. (1976): Information and Control in Organizations. Goodyear, Pacific Palisades.

Mintzberg, H. (1978): Patterns in strategy. Formulation Management Science Day, 99. p.

Mintzberg, H. (1979): The structuring of organizations. Englewood Cliffs, Prentice-Hall, N.J.,

Roóz J. (2001): Vezetésmódszertan. Perfekt Pénzügyi Szakoktató és Kiadó Rt., Budapest, 318. p.

Vermunt, J. (1997): splitswww.vvt.nl/web/fsw/mtv/lem/ manual.pdt Statstische Software: LEM Program Files. 